\title{
Matrimônio: sacramentalidade
}

\author{
Orientador: Prof. Abimar Oliveira de Moraes
}

Pesquisadora: Lucimar Almeida de Souza

Fonte: $\mathrm{CNPq}$

\section{Introdução}

No tema do matrimônio, encontra-se uma série de aspectos teológicospastorais. É fácil perceber que as pessoas buscam a felicidade associada à palavra "amor" e ambas ligadas ao matrimônio. Quando essa tríplice associação vem carregada de um elevado índice de expectativa, muitas vezes, o matrimônio é destinado ao fracasso. Por isso, "amor" deve estar bem definido e bem posicionado na escala de valores de um matrimônio. Desde que fundar comunhões de vida semelhantes às núpcias tornou-se um fenômeno quase natural, o matrimônio já não é mais o único lugar de relações íntimas, socialmente aceito. Esse fato e a consciência da processualidade de relações humanas levam a perguntar pelo sentido de ritos oficiais de contração de núpcias. Além do mais, a teologia sobre o matrimônio cristão carrega o ônus de sua tradição: ainda hoje muitos se deparam, na moral sexual da Igreja, com a desconfiança quanto à corporalidade, ao prazer e à sexualidade, que caracteriza boa parte da história ocidental do matrimônio.

O direito matrimonial, especialmente o da Igreja Católica, revela-se, muitas vezes, como uma regulamentação de pouca ajuda. Também dificulta a compreensão do sacramento para os cristãos engajados na Igreja. O crescente número de cristãos batizados, mas, distanciados da Igreja, torna a junção de casamento e sacramentalidade cada vez mais problemática: pode-se celebrar um sacramento mesmo quando se nega a sacramentalidade? Afinal, que significa o enunciado "o matrimônio é um sacramento"?

$\mathrm{Na}$ longa história desse enunciado, geralmente, discutiu-se mais suas consequências morais e jurídicas (indissolubilidade, competência eclesiástica). Mas, quanto ao conteúdo reinavam, preponderantemente, a incerteza e a inconsequência. Hoje, a teologia luta para dar conteúdo ao sacramento. 


\section{Objetivos}

Esta pesquisa se propõe a estudar os enunciados antropológicos básicos sobre a existência do ser humano como homem e mulher e sua destinação, em princípio, para a relação com um parceiro. Estudar-se-á, também, o matrimônio em sua sacramentalidade. Pesquisar-se-á, outros aspectos teológicos-pastorais relevantes, como a questão da indissolubilidade e o da competência da Igreja para a realização do Sacramento do Matrimônio. 